\title{
Globalization, Cultural Diversity, Education ${ }^{1}$ Globalización, Diversidad Cultural, Educación
}

\author{
Enrique Vez López ${ }^{2}$ \\ Universidad Veracruz \\ vision_ves@yahoo.com.mx
}

Received: November 2, 2016

Accepted: December 5, 2016

How to cite this article (APA, 6th ed.): Vez-López, E. (2017). Globalization, Cultural Diversity, Education. Enletawa Journal, 10 (1), 13 - 24

\begin{abstract}
With the advent of globalization and an ever-growing widespread access to information and communication technologies (ICTs), the cultural minorities become increasingly involved in a process of cultural standardization at the expense of their own cultural identity and language. Different social, economic, and technological elements, together with mainstream education play a very important role in the negation of regional and local cultural identities. These factors lead minoritarian cultural groups to see the dominant culture as more attractive and modern, which often pushes them to abandon their own culture in the hope of better employment perspectives and a better life style for them and their children. In the face of this cultural crisis, intercultural education for all can help stop the erosion of cultural diversity around the world.
\end{abstract}

Key words: cultural standardization, globalization, cultural diversity, education, information and communication technologies, intercultural education.

1 Theme Review

2 Enrique Vez López is a full-time professor at University of Veracuz (UV). He has a Bachelor's degree in English language, UV; He has done a specialization in English Language Teaching at the same university. He holds a Master's degree in Education, at Eastern Mennonite University, VA, USA and a Ph.D. in Language Studies, UV. Among his publications feature those related to language, culture, and English teaching and learning. 


\section{Resumen}

Con el advenimiento de la globalización y el acceso cada vez más amplio a las tecnologías de la información y la comunicación (TIC), las minorías culturales se han visto inmersas en un creciente proceso de estandarización cultural a costa de su propia identidad cultural y su lengua. Distintos elementos sociales, económicos y tecnológicos, junto con la corriente educativa principal, juegan un papel muy importante en la negación de las identidades culturales locales y regionales. Estos factores llevan a las culturas minoritarias a considerar la cultura dominante como más atractiva, y moderna, lo cual a menudo los empuja a abandonar su propia cultura con la esperanza de mejores perspectivas de empleo y un mejor estilo de vida para ellos y sus hijos. De cara a esta crisis cultural, la educación intercultural puede ayudar a detener la erosión de la diversidad cultural alrededor del mundo.

Palabras clave: Estandarización cultural, Globalización, Diversidad cultural, Educación, tecnologías de la información y la comunicación, Educación intercultural. 


\section{Globalization, Cultural Diversity, Education}

The fall of the Berlin Wall in 1989 and the disintegration of the Soviet Union in 1991, marked, on one hand, the end of a world dominated by two opposite ideologies, and on the other, the start of the imposition of the capitalist economic model in the entire planet. Thus, globalization has consolidated as part of a historical process of economic supremacy and world-wide expansion of capitalism. This process implies cultural standardization, or what some scholars call "cultural McDonaldization" (Adda, 1998). Najafi (2015, p. 211-213) states that the effects of McDonaldization can be seen not only in the food industry but also in all aspects of life, culture and education included, as its influence is evident in what is taught and learnt at schools and universities.

Marro Roig, Mosquera Gende and Gómez Lorenzo (2016, p. 2478) point out that "globalization is usually understood as a process that affects economy, politics and culture". They also argue that it is a difficult to define because it affects different fields and involves several areas of daily life. Hence, it also influences education, even though this effect of globalization is paid little attention to (Marro Roig Mosquera Gende, and Gómez Lorenzo, 2016, p. 2478). Deese (as cited in Marro Roig et al., 2016) highlights that globalization may also result "in the loss of a country or region identity." (p. 2478)

Cultural standardization, globalization, exploitation, and domination of indi-ge- nous peoples and minoritarian cultures on the part of the dominant mainstream population have created a situation of endemic poverty that has equated being indigenous with being poor. This has led to a foregone conclusion: to stop being poor, you have to leave behind your own culture and language. There are many cases of well-intentioned people in the media or in everyday interactions who, because of rigid cultural stereotypes, false beliefs, and unconscious attitudes, really believe that indigenous groups in our countries would do much better in every sense if they embraced, unconditionally, the dominant national culture and language (Vez López, 2015).

Modernization has brought with it opportunities that foster the yearning for a better and happier life. To fulfill this dream, people often become involved in a process of cultural assimilation at the expense of their own language and culture, deliberately pushing aside their own lifestyles for a new one. Minoritarian cultures, and with them their languages, are becoming extinct at a fast rate as a result of cultural colonization and globalization (Valijärvi \& Goldstein, 2010). Some of these minorities seethedominantcultureasmore attractive and modern and, consequently, abandon their own culture in the hope of better employment perspectives for them and their children.

This has to do not only with social and economic factors but also with education: an example of this is the fact that the indigenous peoples of Chiapas, Mexico, have borne the brunt of capitalist exploitation for centuries, but it was only 
after 1970, when official public education expanded rapidly throughout the country that bilingual groups began to outnumber monolinguals in the state (MaCaa \& Mills, 1999, p. 117). School plays a very important role in the negation of other cultural identities. The only possible integration of immigrants and indigenous peoples comes through the acceptance of the dominant culture and language.

Whatever the case, there seem to be, at least, two elements that combine to dislodge minoritarian cultures. On the one hand, the willingness of native local groups to accept the dominant culture; and on the other hand, lack of interest and support towards these cultural minorities on the part of governments and the educational system. In other words, what brings about the extinction of local cultures and languages seems to be official neglect and an ever-changing social context that affects the attitudes of local groups through values transmitted via schooling.

Modernization, a globalized economy, and the media are changing cultures around the globe. As the economy becomes more and more integrated, the need for a common language to do business has become stronger. This can jeopardize regional cultures as there is an intimate relationship between language and culture. Mainstream cultural globalization, triggered by economic integration, has enshrined dominant languages such as English, Spanish, Arabic, and Russian, among others, and has placed local weaker languages in direct competition with them, putting them in danger of extinction and threatening their own existence.
Regional minoritarian languages have a tendency to be displaced by more dominant languages. The realities of trade and commerce and the seductive power of pop culture put pressure on the speakers of local indigenous groups so that they learn the dominant languages and, as a result of this, adopt the mainstream culture or face the consequences of failing to do so (Garland, 2006): discrimination, major difficulties to go about their business, limited access to information, and practically no access to education, to mention a few.

The social changes that impact society hold sway over people's choice of language, whether they are aware of it or not. The decline of local indigenous languages and cultures and their eventual disappearance, the need for a lingua fran$\mathrm{ca}$, materialistic attitudes, the adoption of a modern lifestyle, as well as individual independence combined with a weak sense of local identity have assigned indigenous cultures and languages a negative value and status (Janjua, 2011). An example of this is that of the extinction of the Totonaco language in the southern part of the Totonacapan region in the state of Veracruz Mexico (Vez López, 2015; Mackey, 1999).

Additionally, the media and telecommunications have put pressure for standardization, stifling even more local variations. This is leading to a rapid elimination of minoritarian cultures. It is true Economics is the root of all changes; however, it does not completely explain this historical process; it is also the evolution of technology, which has revolutionized information and communications, which 
has impacted the culture domain. Postman (1993) provides an example of how technology has changed dramatically the way children's acquisition of knowledge has changed significantly - practically all over the world - since the advent of computer-assisted standardized testing.

"Technology makes our lives easier, cleaner and longer" (Postman, 1993, p. xii). However, "because of its intimate and examination of its own consequences" (Postman, 1993, p. xii) inevitable relationship with culture, technology does not invite a close. A case in point is television, which has created a sort of monopoly of knowledge the masses trust blindly. Most people trust television and the media in general because what is said and shown so publicly for everyone to hear and see cannot be a lie. Television for the most part broadcasts stereotyped images of people who are fair-skinned, speak a dominant language, wear modern clothes, shop in malls, convenience stores and supermarkets, enjoy fast food, drive a car, are learning or already speak English, etc. In sum, they are happy and successful.

There is no question that computers and the Internet have made it easier to share knowledge and communicate instantly with people all over the world. But we cannot overlook the costs. It has flooded web sites with advertisements, email accounts with junk mail. It has made people easy targets of advertising agencies, political organizations and governments. It has substituted conversations for Facebook browsing and children's playground games for video games, all of which impacts local cultures unless they are savvy and can come up with a way of using technology to strengthen their own culture and community ties.

Technology is changing our understanding of reality and of things that should matter to us. We need to consider how technology can alter our understanding and perception of community, culture, family, history, education, social life, traditions, and values. Once our awareness of where we are going is raised, we have to make sure that it leads to more respect of cultural differences, more intercultural education, more tolerance, less discrimination; in other words, more cultural diversity.

Cultural diversity, understood as an array of cultural and/or ethnic groups coexisting within a larger social community, is just as important as biodiversity. It is our duty to preserve both, but globalization, the way it has developed at present, has a tendency to make cultures uniform and destroy them. In this respect, neither technology nor school has done much to stop this process. On the contrary, school has become an instrument of cultural domination because it fosters the imposition of official mainstream culture and language.

Official schools in Latin American countries have been a means to impose western culture, favoring written culture over oral traditional culture. They have created a false opposition between modernity and tradition, in many instances, and have favored a specific way of constructing knowledge that has sacrificed an enormous cultural heritage. Modernization and globalization have imposed a unique cultural model for 
all the peoples of the world without any respect for cultural diversity.

This perspective has labeled indigenous peoples and other cultures as primitive, and considers them an obstacle to the globalization of capitalism. The world is very complex and is made up of a cultural and ecological diversity that must reject any attempt of one culture trying to impose its own universal truths over other cultures.

We must try to imagine a diverse, multicultural society capable of fostering equity and justice within that diversity, a society that is open and tolerant of all the differences that characterize multicultural groups that stretch beyond political borders. One of the greatest challenges of our times is to learn how to live together within a multicultural framework. This is a question that must be answered by education. We must learn how to find the answers to these issues through intercultural dialogue, humility, and dignity, keeping away from simple solutions that are exclusive and do not take into account the complexity of the world we live in.

Public education has to be the foundation of democracy, a way to pursue and establish real political and cultural equity. It must provide the means to reflect upon our reality, evaluate it, and change it, if it is necessary (Longo, 2001). Education must not be one more item in the great global supermarket. Knowledge and education cannot become goods that can be sold and bought, as the neo-liberal ideology proposes with its opposition to any political philosophy that supports the role of the state in public education. The neo-liberal trend is to privatize education in order to reduce state social expenditure.

Thus, in the face of neo-liberalism and westernization, cultural diversity must emerge as the positive expression of a general objective that seeks to achieve the protection and preservation of the cultures of the world. At present, it is the culture of the masses that has been imposed through the media, television, and propaganda (Schiller, 2000). This has given unity to our world but it is eroding national identities, substituting them by an American cultural model.

This cultural standardization has lead to an Americanization of our way of life turning it into one that indulges in consuming (clothes, food, cars, entertainment, etc.), and wasting. This is only one more chapter of the historical process that started in Europe in the XV century. At present, the Americanization of culture is the most grotesque aspect of that process in which the ever-expanding capitalist system transforms everything it touches into merchandize. This process started in the 50s with cultural industrialization, a process similar to urbanization that disintegrates communities stripping them off their identities (Morin, 1993).

An article published by the BBC online, signed by Pagel (2014) is an example of this. Now, this was published 3 years ago, so things have certainly changed considerably. In November 2014, Starbucks, a coffee chain that started with one single outlet in Seattle 50 some years ago, had grown to 20, 000 shops all over the world. This means that you could be in New York, Mexico City, Thailand, Japan, 
or Argentina, and drive or walk to your nearest store and have your latte that tastes almost the same as any other in the world, served in the same custom-made cups by people wearing the same clothes, and smiling identically as their counterparts in Seattle. We are being part of a cultural trend that the world had not witnessed until very recently.

Of course, it is not just Starbucks. It is also MacDonald's and Burger King and Coca Cola and Facebook and Apple and a myriad of other ubiquitous brands, whose presence you are likely to feel all over the world.

This Americanization of the world, which translates into the cultural destructionoflargegeographicalareas, istheresult of a neo-colonial cultural domination that imposes supposedly universal values that have corrupted and ruined many other cultures in the world (Ramonet, 1997). Many nations and cultures today undergo a crisis of identity. Their citizens have been stripped off the essential traditional cultural references. They have lost their identities in a context of constant change and technological evolution to which they must adjust (Ramonet, 1997). Economic and cultural globalization has damaged the complex cultural and economic tissue via technologies such as television, videogames and the Internet. All these changes have produced a cultural shock that has weakened the values and traditional references of social groups (Ramonet, 1997).

The growing individualism of western culture has generated all sort of conducts associated to competitiveness, pragma- tism, utilitarianism, and the calculation of profit in our interpersonal relationships, which has destroyed our sense of solidarity. This trend has led to the degradation of traditional ways of life. Today, communities are confronted with a change in customs, behavior patterns, and the deterioration of its core values (Ramonet, 1997).

How can we protect the ancient values of cultural diversity from the overwhelmingoppression of cultural standardization? Perhaps history can help us answer these questions since these conflicts are not new. Let us remember the huge cultural clash that took place in the XV and XVI centuries between European culture and the peoples of the Americas, or the confrontation of faith and logical truth during the Renaissance. Now we face a new crisis, one that is cultural, linguistic, demographic and economic, one that has unleashed a debate between diversity and homogenization.

Education seems to be the tool of choice to start to overcome such crisis. In this fight, education has at times played and must continue to play a decisive role as a point of encounter and dialogue among cultures. According to UNESCO (2006):

In a world experiencing rapid change, and where cultural, political, economic and social upheaval challenges traditional ways of life, education has a major role to play in promoting social cohesion and peaceful coexistence. Through programmes that encourage dialogue between students of different cultures, beliefs and religions, education can make an important and meaningful contribution to sustainable and tolerant societies (p. 8). 
Intercultural education can create the conditions that will enable cultures to complement one another. It can create a niche for cultural diversity, tolerance, dignity, and mutual respect. In the words of UNESCO (2006), "intercultural Education is a response to the challenge to provide quality education for all" (p. 8). The Universal Declaration of Human Rights (UN, 1948) explicitly expresses the need to safeguards education as a fundamental human right:

Education shall be directed to the full development of human personality and to the strengthening of respect for human rights and fundamental freedoms. It shall promote understanding, tolerance and friendship among all nations, racial and religious groups, and shall further the activities of the United Nations for the maintenance of peace (Art. 26.2).

Even though cultural diversity is currently undergoing a process of erosion, and even destruction in some cases, it is still alive because culture is part of a living process. It is dynamic and transforms itself constantly locally and globally. However, it will not last very long unless we act now. But where to start?

The answer to this can be intercultural education for all. Intercultural education can be achieved through:

The inclusion of multiple perspectives and voices. The development of inclusive curricula that contain learning about the languages, histories and cultures of non-dominant groups in society is one important example. The issue of language(s) of instruction and language teaching is another crucial element of effective
Intercultural Education. (UNESCO, 2003, as cited in UNESCO, 2006, p. 19)

However, UNESCO (2006) points out that this kind of education cannot just be added to the curriculum as some sort of appendix as the whole learning environment and other aspects of educational processes, e.g. "school life and decision making, teacher education and training, curricula, languages of instruction, teaching methods and student interactions, and learning materials" (p. 19), have to be considered.

Delors (as cited in UNESCO 2006, pp. 19,20) singles out four pillars of education: Learning to know, Learning to do, Learning to live together, and Learning to be. The third one: Learning to live together is characteristic of intercultural education as it aims at "Developing an understanding of other people and an appreciation of interdependence- carrying out joint projects and learning to manage conflicts - in a spirit of respect for the values of pluralism, mutual understanding... peace" (UNESCO, 1996, as cited in UNESCO, 2006, p. 20)

In other words, within the frame of an educational system, our students need to develop skills and adopt values that enable him or her to cooperate and collaborate with diverse people and social groups in a context of multiculturalism. However, we, teachers, schools and universities, need to set the example and be guided by basic principles of intercultural education already identified by UNESCO (2006):

Principle I. Intercultural Education respects the cultural identity of the learner through 
the provision of culturally appropriate and responsive quality education for all.

Principle II. Intercultural Education provides every learner with the cultural knowledge, attitudes and skills necessary to achieve active and full participation in society.

Principle III. Intercultural Education provides all learners with cultural knowledge, attitudes and skills that enable them to contribute to respect, understanding and solidarity among individuals, ethnic, social, cultural and religious groups and nations. (p. 32)

Principle III covers several issues taken from multiple sources that have to do with intercultural training and education taking place at school level. They cover adequate teaching and learning methods; the acquisition of skills to communicate and co-operate beyond cultural barriers and to share and co-operate with others; and the teaching and learning of foreign languages. In my humble opinion, this last point is highly desirable. However, it would be even better to start studying and learning our local languages; they are being driven to extinction by lack of interest in them from those who do not speak them, but also those who are speakers of the language themselves. This is happening due to a good number of reasons that I havealready discussed above. It also addresses adequate teacher initial education and permanent professional development, and the development of curricula. However, I will focus only this last issue cited here because I truly believe that, at an educational level, discovery, critical awareness, knowledge, understanding and respect are all key elements in our attempt to foster cultural diversity values in education. This is where we should probably start: with curriculum development that, I quote, addresses

- The discovery of cultural diversity, awareness of the positive value of cultural diversity and respect for cultural heritage.

- critical awareness of the struggle against racism and discrimination;

- Knowledge about cultural heritage through the teaching of history, geography, literature, languages, artistic and aesthetic disciplines, scientific and technological subjects.

- Understanding and respect for all peoples; their cultures, civilizations, values and ways of life; including domestic ethnic cultures and cultures of other nations.

- awareness of the increasing global interdependence between peoples and nations

- Awareness not only of rights but also of duties incumbent upon individuals, social groups and nations toward each other.

- Understanding of the necessity for international solidarity and cooperation.

- Awareness of one's own cultural values that underlie the interpretation of situations and problems as well as the ability to reflect on and review information enriched by the knowledge of different cultural perspectives.

- Respect for differing patterns of thinking. (UNESCO, 2006, p. 37)

All around the globe, others have already taken the initiative and projects are being developed and standards are being set in order to protect and promote cultural diversity (UNESCO, 2006). The following are only but a few examples of measures that are being taken in Africa, Latin America, Asia and Europe to preserve cultural diversity: 
The Charter for African Cultural Renaissance, adopted in 2006 (as cited in UNESCO, 2006), has highlighted the urgent need to come up with an educational system that embodies the African values, promotes African languages, and seeks to protect and preserve tangible and intangible cultural heritage in the fields of History, Traditions, Arts and Handicrafts, Knowledge and Know-how. There is a growing awareness of Africa's rich heritage and the resolve to preserve and manage such diversity of cultures, languages, and heritage.

Likewise, in Latin America, The Salamanca Declaration (UNESCO, 1994, as cited in UNESCO, 2006), has placed priority on cultural rights and cultural heritage, both tangible and intangible. According to UNESCO (2006) “The growing awareness of the continent's cultural diversity has led not only to a rediscovery of the indigenous cultures threatened by large-scale deforestation and growing impoverishment" (p. 24), but also to "the need to ensure cultural mixing and multiple identities" (p. 24). Specifically, in Bolivia, Ecuador and Peru, political recognition of the rights of indigenous peoples has led to reforms, land redistribution and other social advantages dependent on indigenous status and mastery of an indigenous language (UNESCO, 2006).

In the case of the ArabStates, the Riyadh Declaration of the League of Arab States (as, cited in UNESCO, 2006) expresses the determination to protect the Arab identity, its components and bases, and strengthen Arabism as a unified cultural identity, with the Arabic language as its means of expression. The goal is to preserve its heritage, diversity and plurality, while addressing issues of identity arising from conflicts in the region.

The Council of Europe has also has also been working to ensure recognition of the importance of cultural diversity as an essential condition of human society. The December 2000 Declaration on Cultural Diversity (as cited in UNESCO, 2006) stresses the co-existence of culturally different practices and invites members of the Council of Europe to support cultural and linguistic differences.

It stands clear that a large part of mankind is opposing a formidable resistance to the expansion of cultural standardization. Notwithstanding the difference in the impact of globalization in diverse regions of the world and in spite of a tremendous disparity of geographical, historical and political contexts, "A broad convergence of views on the safeguarding of cultural diversity is thus apparent at the regional level" (UNESCO, 2006, p. 25). Many people are fighting cultural globalization and searching for the vital references they need to survive in a changing and often unjust world. The globalization of capitalism has caused many social organizations to find alternatives, and fight against its domination. "These varied approaches testify to the common concern to identify ways of adequately addressing the wide-ranging challenges inherent in the protection and promotion of a common cultural heritage" (UNESCO, 2006, p. 25). 


\section{References}

Adda, J. (1998). La Mondialisation de l'economie, 1. Genese (3rd ed.). Paris : La Decouverte.

Fernando, C., Valijärvi R. L., and Goldstein A. R. (2010). A Model of the Mechanisms of Language Extinction and Revitalization Strategies to Save Endangered Languages. Human Biology, 82 (1), 47-75.

Garland, E. (2006). Can minority languages be saved? The Futurist, 40 (4), 31-36.

Janjua, F. (2011). Causes of Decline of Yadgha Language. Canadian Social Science, 7 (2), 249-255.

Longo, T. (2001). Philosophies et politiques neo-liberales de la education dans le Chili de Pinochet 1972-1983. Paris: L'Harmattan.

Macaa, R., and Mills, H. (1999). Is education destroying indigenous languages in Chiapas? In A. Herzfeld, y Y. Lastra (Eds.), Las causas sociales de la desaparición y del mantenimiento de las lenguas en las naciones de América (pp. 117-136). Hermosillo, México: Universidad de Sonora, UNISON.

Mackay, J. C. (1999). Dos casos de mantenimiento lingüístico en México: el totonaco y el véneto. En A. Herzfeld, y Y. Lastra (Eds.), Las causas sociales de la desaparición y del mantenimiento de las lenguas en las naciones de América (pp. 7798). Hermosillo, México: Universidad de Sonora, UNISON.

Marro Roig, B.C., Mosquera Gende, I., and Gómez Lorenzo P. (2016). Education for globalization: cultural diversity and multilingualism. Paper presented at the EDULEARN16 Conference 4th-6th July 2016, Barcelona, Spain: Universidad Nacional de Educación a Distancia. Retrieved from: http:/ / www2.uned.es/ca-tortosa/ Biblioteca_Digital/Biblio/Barbara_ Marro/Barbara_\%20Comunicacion_ EDULEARN16.pdf

Morin, E., Kern, A. B. (1993). Terre Patrie. Paris and Seuil.

Najafi, H. (2015). McDonaldization, Society, and Education. International Journal of Humanities and Social Science, 5, 9(1) 2011-214. Retrived from: http:/ / www.ijhssnet.com/journals/Vol_5_ No_9_1_September_2015/19.pdf

Pagel, M. (2014). Does globalization mean we will become one culture? Retrieved from : http://www.bbc.com/future/ story/20120522-one-world-order

Postman, N. (1993). Technopoly: the surrender of culture to technology. New York: Vintage Books

Ramonet, I. (1997). Geopolitique du Chaos. Paris: Editions Galilee

Schiler, H. I. (2000). Décervelage à l'américaine. La culture, les élites et le peuple. Manière de voir: Le Monde Diplomatique, (57) 29-32.

UNESCO (2006) UNESCO Guidelines on Intercultural Education. Paris. Retrieved from:

http:/ / unesdoc.unesco.org/images / 0014/001478/147878e.pdf

UNESCO (2009). World Report. Investing in Cultural Diversity and Intercultural 
Dialogue. Retrieved from : http:// www.unesco.org/library/PDF / Diversity.pdf

United Nations (1948) Universal Declaration of Human Rights. Paris. Retrieved from:

http://www.ohchr.org/EN/UDHR/ Documents/UDHR_Translations / eng.pdf

Vez López, E. (2015) Dinamicas familiares en el desuso y posible extinción del totonaco de Misantla, Veracruz. Germany : GRIN Verlag. 